\title{
Nature and Control of Potato Virus Diseases
}

\author{
By Prof. Paul A. Murphy
}

$\mathrm{T}^{\mathrm{H}}$ $\mathrm{HE}$ discussion on September 15 in Section M (Agriculture) of the British Association on "Scientific Aspects of Potato Growing" proved useful and timely. Inevitably the discussion was entirely pathological, ranging from virus diseases to potato sickness caused by the eelworm, Heterodera Schachtii, which may reduce the value of potato land from $£ 2$ to $10 \mathrm{~s}$. per acre. Most of it, however, concerned virus diseases and the raising of healthy seed potatoes. The magnitude of the question is shown by the fact that there are half a million acres of potatoes in England and Wales, and of these some 120,000 acres are planted with Scottish or Irish seed potatoes annually. The balance is planted with local seed, and it is a question to what extent this could be profitably replaced, for fresh seed is estimated to increase yields by one ton per acre. Much also could be done, as has been shown by Bryan at Ormskirk, to maintain the health of the imported seed so as to make it last longer.

The best way to improve the potato crop as a whole, however, is to increase the vigour of the imported seed stocks. It should now be possible to guarantee the entire absence of leaf roll, which is the principal cause of degeneration. This disease depends on the aphis, Myzus persica, for its spread, and Davies has shown that its prevalence depends on such simple physical factors as temperature, humidity, wind, and system of cropping. It hibernates on Brassicas and migrates to potatoes from May on, whenever the temperature rises above $55^{\circ} \mathrm{F}$. (optimum $70^{\circ}-80^{\circ} \mathrm{F}$.), the humidity is 70 per cent or less, and the wind does not exceed 5-6 m.p.h. This knowledge enables one to avoid the indifferent districts, but not to turn them into good ones. It also explains why the best seed is to be found in exposed, wet and windy places, particularly near the sea, where farming is mainly pastoral and potato fields isolated. The connexion of good seed with islands is proverbial.

The potato mosaic question has been in danger of becoming a mystery, but the time has come at last when a clarification is possible. Some of the difficulties have been artificial ones. In the laboratory a single virus can be made to produce mottling, streaking, or no symptoms, by choice of the proper variety, but the general rule in Nature is that the virus is either carried or expresses itself as a mottle only. In other words, those varieties in which a virus causes streak, as virus $X$ does in
Arran Crest or virus $A$ in British Queen, are free from that infection, for the virus either kills the plant and tubers, or kills itself while localized in the necrotic spots. Virus $Y$, which is the usual cause of streak, is sometimes an exception, but the general rule holds good : one virus, one disease. This is an enormous simplification.

It is probable that no virus is entirely harmless, although in some cases no natural spread or effect on yield has been demonstrated. Omitting such, it is found that the principal potato mosaics are caused by the four viruses $X, F, Y$ and $A$, alone or in combination, and these form the types of three natural groups, viruses $Y$ and $A$, though distinct, being at present placed together on account of the occurrence of intermediate forms. These groups are very shortly characterized as follows :

Group 1. X-type viruses. Mottle on Datura and tobacco; pass $L 3$ filter; vector unknown (not Myzus persicce); typical disease, simple mosaic.

Group 2. $F$-type viruses. Spots on Solanum nodiflorum and Capsicum annuum; carried by tobacco and Datura; held by $L 3$ filter; vector, Myzus persicce under certain conditions; typical disease, yellow or aucuba mosaic.

Group 3. $Y$-type viruses (including virus $A$ and vein-banding virus). Vein-banding on tobacco; not inoculable to Datura; held by L3 filter; vector, Myzus persicce; typical disease, veinal mosaic or leaf-drop streak.

The four viruses mentioned, together with their four combinations, produce eight diseases as follows, though complexes of more than two terms also occur :
1. $X=$ simple mosaic.
2. $F=$ yellow mosaic.
3. $A=$ veinal mosaic
4. $Y=\left\{\begin{array}{l}\text { veinal mosaic. } \\ \text { leaf-drop streak }\end{array}\right.$
5. $X+F=$ interveinal mosaic.
6. $X+A=$ crinkle.
7. $X+Y=\{$ rugose mosaic.
8. $A+F=$ double virus aucuba.

The first three diseases are normally passed over in the field, the eighth is not very common, and the remainder make up the mosaic of the practical man. These, as will be seen, are caused by a virus transmitted by Myzus persicce, either alone or in combination with $X$. This, therefore, reduces the mosaic problem to two dimensions : the control of Myzus persica, which is only the leaf roll problem over again with the additional complication of carriers, and the control of virus $X$. The latter is still an enigma, for though it spreads so 
freely as to be almost ubiquitous, occurring for example throughout the variety Up-to-Date, and in all American commercial potatoes without exception, its vector is unknown. It infiltrates rapidly into virus-free stocks even when grown in isolation in the best districts, and is not entirely unknown in experimental glasshouses. As part of the basis of all the severe mosaics it is an active danger, but the question still awaits answer whether it is economically possible or necessary to control it as well as the aphis-borne viruses.

The viruses mentioned are not uniformly distributed throughout Great Britain and Ireland. In the best districts, leaf roll is absent, $Y$ is rare, $A$ is more common and $X$ is nearly universal, while in the south-east leaf roll and virus $Y$ become comparatively common. The useful life of a variety depends on its reaction to the local viruses, and the moderate reactors suffer most and last shortest, a good example being Arran Chief. The carriers and strong reactors escape best. Outstanding varieties, such as the famous Up-to-Date and British Queen, are intolerant of $A$ and probably resist infection with it as well. Up-to-Date tolerates $X$ and British Queen resists it. It appears to be the reaction to these two viruses which determines the survival of a variety in Great Britain. If it tolerates $Y$ as well so much the better, but our best potatoes lack this quality, a fact which explains the failure of Up-to-Date in the interior of the United States and Canada, as probably also in Central Europe. The control of virus $Y$ at home depends on the use of Scottish and Irish seed potatoes.

\section{Dental Caries and Diet}

$\mathrm{I}^{\mathrm{N}}$ spite of the facts that there are more dental clinics, that many more people brush their teeth and that more dental treatment is practised to-day than ever in the world before, dental disease seems to be as prevalent as it has ever been, especially among civilized peoples. The experimental work of Mrs. Mellanby has shown that there is an intimate relationship between the diet and the structure of the teeth in both animals and man, and that there is similarly a close relationship between structure and liability to caries in man. It remained to be proved that the incidence and progress of the disease could be influenced by alterations or additions to the diet.

The results obtained in the first stages of the investigations carried out with this object have already been referred to in these columns (NATURE, 129, 83; 1932 : 133, 820; 1934). The final report* of the Committee for the Investigation of Dental Disease describes the influence of diet upon caries in children's teeth and shows that the teeth, like other organs of the body, are strongly influenced by nutritional factors brought to bear upon them, whether through their blood supply or the saliva. The dental decay that developed in the children receiving an addition of vitamin $\mathrm{D}$ to their diet was definitely less than in the control children not receiving extra vitamin, and its influence in inhibiting the initiation and spread of caries was especially impressive when the addition was made during the period of development and before full eruption of the teeth.

* Medical Research Council. Special Report Series, No. 211 : The Influence of Diet on Caries in Children's Teeth (Final Report). By the Committee for the Investigation of Dental Disease (assisted by Alan Deverall and Mabel Reynolds). Pp. ii +137 . (London: H.M. Stationery Office, 1936.) 28. net.
The investigations were made in three similar institutions in the neighbourhood of Birmingham, maintained on the Cottage Home System, under the Poor Law authority and later under the local education authority. It was at first hoped to divide the children in each institution into three groups, each receiving a different supplement, so as to avoid the possible influence of slightly differing conditions in the homes affecting the results, but administrative difficulties prevented this and all the children in one home were given the same addition. Analysis of the basal diets showed that they were fairly similar in the three institutions : the variations, described in the report, probably did not affect the general conclusions drawn from the results obtained. Three experiments were carried out. In the first, the three institutions had daily additions to the diet of treacle (2842 gm.), olive oil (14-21 c.c.) and cod liver oil (14-21 c.c.; 50-100 units of vitamin D per c.c.) respectively. In the second, carried out in one institution only, one group of children received the olive oil and the other vitamin $\mathrm{D}$ in olive oil (625 units per c.c. : 14-21 c.c.). In the third, the children were younger ( $2-5$ years old) instead of 5-14 years old, and the additions were treacle, vitamin $\mathrm{D}$ in olive oil and cod liver oil in daily doses of $7 \mathrm{gm}$. or 7 e.c., in three different institutions. Although about 1,600 children were under observation for varying lengths of time, the number who received the special additions for the full period of three years was much less.

Six-monthly examinations were made of the mouth and of the general physical condition with 